\title{
Magnetic resonance imaging of racemous cysticercosis of the cauda equina
}

\author{
Ressonância magnética de paciente com cisticercose \\ racemosa da cauda eqüina
}

\section{Leodante Batista da Costa Junior ${ }^{1}$, Sandro Pedroso Lemos ${ }^{1}$ and José Roberto Lambertucci ${ }^{2}$}

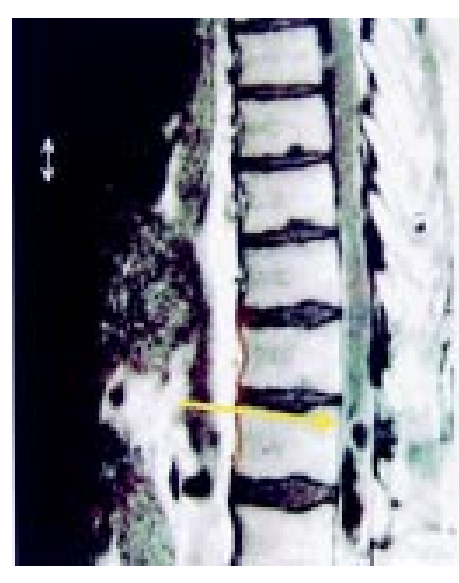

A

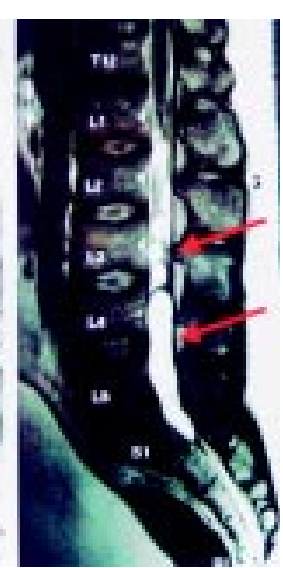

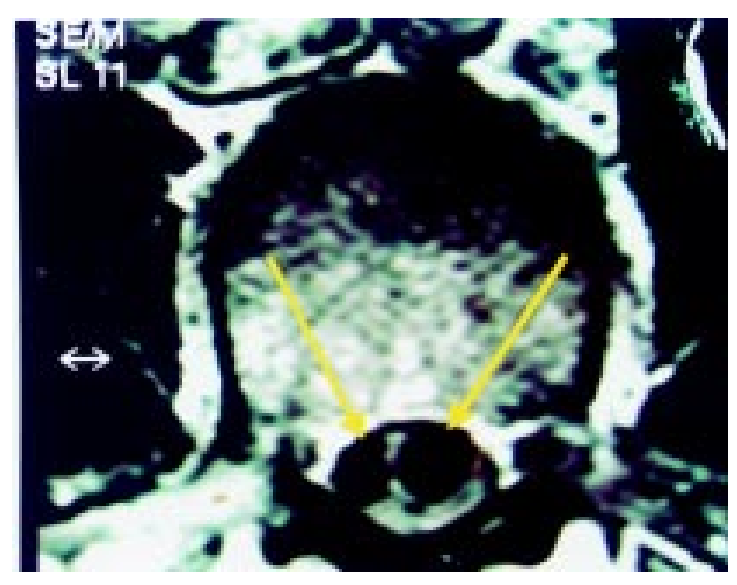

B

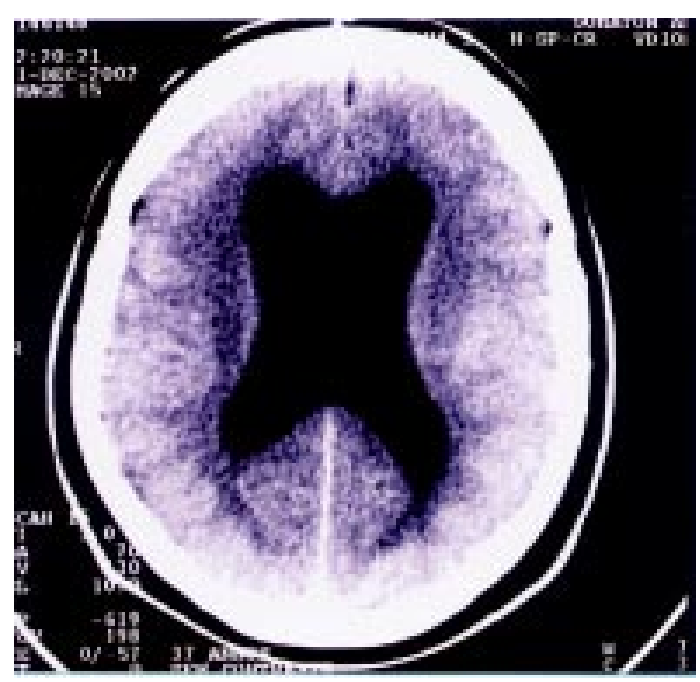

C

1. Serviço de Neurocirurgia do Hospital da Baleia, Belo Horizonte, MG. 2. Serviço de Doenças Infecciosas e Parasitárias da Faculdade de Medicina da Universidade Federal de Minas Gerais, Belo Horizonte, MG.

Address to: Dr. Leodante Batista da Costa Junior. Rua Três Corações 13/302, Bairro Prado, 30480-110 Belo Horizonte, MG, Brasil.

Recebido para publicação em 5/8/2003

Aceito em 20/8/2003 
A 37-year-old man presented with low back pain for the last 6 months followed by sensation of numbness in the lower limbs that evolved with paraparesis, urinary retention and impotence. Subsequently, he lost control over the bowel function. Neurological examination revealed increased muscle tone along with grade zero power in both lower limbs. Knee and ankle jerks were exaggerated. Nine months prior to admission, a type II diabetes mellitus was diagnosed and he has been taking insulin ever since. MRI revealed multiple cystic lesions in the cauda equina opposite the L1-S1 vertebral bodies with no involvement of the spinal cord (Figure A: sagittal section T1-weighted image after contrast with cystic lesions on the left side-yellow arrow -, and T2-weighted image on the right - red arrows pointing cystic lesions). The cysts were hypointense on T1-weighted images (Figure $B$ : horizontal section - yellow arrows) and hyperintense in T2-weighted images (Figure A - red arrows). Computerized tomography of the brain showed moderate ventricle dilatation (Figure $\mathrm{C}$ ) with no intra or extra axial lesions. He was submitted to laminectomy and the cysts were surgically removed. An intense inflammatory process (arachnoiditis) involving the nerve roots of the cauda equina was reported. Histology of the surgical specimen confirmed the diagnosis of racemous cysticercosis. He improved quickly after surgery. Three months later, at the outpatient clinic, he walked with support, resumed sphincter control of the bladder and bowel and had no more pain. Ten months later he returned to hospital walking with crutches, with hypoesthesia and paresthesia on the left leg and urinary incontinence. He refused treatment with albendazole and steroids.
O paciente de 37 anos de idade queixava-se de dor lombar, acompanhada de dormência nas pernas que evoluiu com paraparesia, retenção urinária e impotência de início há seis meses. Houve, a seguir, perda de controle do esfíncter anal. O exame neurológico revelou aumento do tônus muscular em membros inferiores e força zero nas pernas. Os reflexos patelar e aquileu estavam aumentados. Nove meses antes da admissão hospitalar, diagnosticou-se diabetes melito do tipo II e, desde então, vem recebendo insulina. A ressonância magnética evidenciou a presença de múltiplas lesões císticas na cauda eqüina que se estendem de L1 a S1, sem acometer a medula espinhal (Figura A: o corte sagital, com imagem ponderada em T1, após contraste, revela lesões císticas na figura da esquerda - seta amarela -, e também na imagem ponderada em T2, à direita, - setas vermelhas). Os cistos mostram-se hipointensos em T1 (Figura B: corte axial - seta amarela) e hiperintensas em T2 (Figura A - setas vermelhas). A tomografia computadorizada do cérebro demonstrou dilatação intraventricular moderada (Figura C) sem lesões intra ou extra-axiais. Ele submeteu-se à laminectomia e as lesões císticas foram removidas. Observou-se processo inflamatório intenso da aracnóide e que envolvia as raízes nervosas da cauda eqüina. O exame histológico confirmou o diagnóstico de cisticercose racemosa. Houve melhora clínica após a cirurgia. Três meses mais tarde, ele andava com apoio, relatava melhora do controle de esfíncteres e não havia dor lombar. Dez meses depois, ele retornou ao hospital andando com a ajuda de muletas e queixando-se de hipoestesia e parestesia na perna esquerda, além de incontinência urinária. Ele rejeitou, por ora, o tratamento com albendazol e corticoesteróides.

\section{REFERENCES}

1. Dantas FLR, Fagundes-Pereyra WJ, Souza CT, Vega MG Souza AA. Cisticercose intramedular: relato de caso. Arquivos de Neuropsiquiatria 57:301-305, 1999.

2. Parker F, Hladky JP, Breton JO, Mignard C, Laporte JP, Bousquet $C$. Racemous cysticercosis of the cauda equina and cystic arachnoiditis. Apropos of 2 cases. Neurochirurgie 34:280-285, 1988

3. Takayanagui OM, Leite JP. Neurocisticercose. Revista da Sociedade Brasileira de Medicina Tropical 34:283-290, 2001. 